\title{
CHICO DAS ONÇAS
}

\author{
Lancast Mota
}

Em Fortaleza, CE, no começo dos anos 70, a vida era muita mais tranqüila e menos ansiosa: não havia internet, nem videogames, nem TV a cabo, a televisão entrava no ar às 3 da tarde e às 11 da noite saía do ar e os dias tinham 24 horas, pelo menos tínhamos essa sensação. À noite, as pessoas colocavam cadeiras nas calçadas e ficavam conversando, contando histórias, piadas e, claro, fofocando. A iluminação dos postes dava um clima urbano às conversas, despindo-as do mistério. Mas, o que eu gostava mesmo eram as férias escolares de junho, quando o meu pai me levava para a casa do meu avô Valdivino, que morava no meio do sertão. O poste de energia elétrica mais próximo ficava a muitas léguas de distância. O meu avô era uma espécie de aglutinador cultural do lugar. Nas noites de sexta e de sábados, os amigos, os compadres e os amigos dos compadres vinham tomar café com bolo de milho, contar e ouvir histórias. Às sextas-feiras, eram contadas as histórias de assombrações e, aos sábados, as cantorias, os repentes e os cordéis. Eu tinha uma predileção especial pelas noites de sexta. Quando eu ia dormir, invariavelmente, estava com os olhos arregalados e me cagando de medo das histórias que ouvira. Ficava enrolado na rede com um olho para fora, tão excitadamente assustado que não via o sono chegar. Ainda faltava uma semana para as festas juninas, era sexta-feira, tomei banho, jantei e fiquei esperando. Esperando o terror que se aproximava. Ao cair da noite, as pessoas foram chegando. Luz, só da lua no céu e do candieiro na sala. As pessoas se reuniam em frente à casa. Após os cumprimentos e informes sobre os que não compareceram, um começava uma conversa, o outro puxava uma perna para outra história. Foi nessa noite que pela primeira vez vi Chico das Onças, famoso contador de histórias, e, segundo as boas línguas, de mentiras. O meu avô dizia que uma mentira bem contada era melhor que uma verdade mal contada, de modos que todos tinham o Chico em boas graças. Meu pai me contou depois que o Chico das Onças tinha esse nome por causa de uma feita, quando ele enfrentou sozinho, com uma lamparina apenas, três onças (mas essa é outra história). O Chico era o melhor contador de história de assombração da região, conhecia história de lobisomem como ninguém (no sertão, o lobisomem é diferente dos da literatura européia: o sujeito tem que ser o $13^{\circ}$ filho, se despojar nu onde os cavalos dormem, rejeitar Jesus por três vezes e amaldiçoar pai e mãe - depois de transformado, o Lobisomem corre 49 léguas numa noite, ele corre de quatro apoiado nos cotovelos), mas naquela noite ele resolveu contar uma história diferente. Em todo o sertão não havia uma só pessoa que não se assombrasse com os causos dele.

Era a história do Nego da Peixeira. O Nego era um bandido amaldiçoado que era meio vivo e meio morto, por conta das maldades que fez durante a seca de 1915. Ele escapou da seca comendo orelhas das pessoas que encontrava, ele arrancava as orelhas com as pessoas vivas. Quando foi preso pela volante em 1917, foi encontrado com ele um saco cheio de orelhas salgadas. O Chico foi contando as barbaridades do Nego da Peixeira com uma alternância vocal assombrosa. Ninguém, além do Chico, falava, alguns suavam, outros colocavam as mãos nas orelhas. Por volta da meia-noite, o causo acabou. Todos se despediram e foram embora juntos numa mesma direção, menos o Chico que foi pelo caminho do riacho. Lavei os pés e fui me deitar tremendo mais que vara verde, não vi o sono chegar, acho que desmaiei antes.

Quando amanheceu, ao abrir a porta, o meu avô encontrou o Chico dormindo no batente. Explicação pra cá, explicação pra lá e o Chico contou o ocorrido: quando estava indo embora, a lua

\footnotetext{
Lancast Mota é desenhista e roteirista, tendo criado diversos personagens para animação, cinema e televisão. Cearense, mora já há
} alguns anos em Porto Alegre. 
estava encoberta e ao fazer a curva duma descida que ia dar no riacho, ele percebeu que ao lado duma moita havia uma pessoa. Aprumou os olhos e viu a silhueta de um enorme caboclo com uma faca na mão. Era o Nego da Peixeira, só podia ser. Por mais macho que ele fosse não seria páreo para um sujeito do outro mundo. Então Chico ficou do lado de cá, espiando e esperando que o Nego fosse embora e nada dele ir. Só se mexia com a peixeira na mão à espera de um incauto. Como ele permanecia ali, Chico resolveu voltar e dormir na porta da casa para não acordar ninguém. O meu avô não tinha o Chico na conta de cabra frouxo, então, ele, meu pai, meu tio e o Chico foram examinar o lugar. Chegando ao local indicado, não acharam nada, nem mesmo pegadas. Então o tal Nego da Peixeira era mesmo um sujeito do outro mundo. O meu avô ficou encafifado e quis tirar a história a limpo. O Chico das Onças passou o dia na casa do meu avô, quando chegou a noite, formaram um grupo, armados com uma espingarda, facões e um lampião a gás. Era uma noite escura e ao chegarem na curva mencionada, todos pararam estarrecidos: lá embaixo viram a sombra de um sujeito que se mexia segurando alguma coisa na mão. $\mathrm{O}$ grupo desceu preparado para o entrevero, mas, ao chegarem ao local e ao aumentarem a chama do lampião, descobriram que o tal Nego era apenas um galho de árvore que se mexia com o vento. Vexado, Chico foi embora sem se despedir. As festas juninas foram o espetáculo de sempre, as férias acabaram e voltei para Fortaleza.

No ano seguinte, fui para a casa do meu avô de novo. A primeira coisa que fiz foi perguntar pelo Chico das Onças. Meu avô disse que ele tinha ido para São Paulo e nunca mais ninguém teve notícias dele. 